\title{
Blood Constituents, Antioxidant Activities and Hormonal Profile in She-camels (Camelus dormedarius) during different Physiological Statuses in the North Western Coast of Egypt
}

\author{
Ibrahim S Abd El-Hamid
}

Department of Animal and Poultry Physiology, Division of Animal and Poultry Production, Desert Research Center, 1 Mathaf El Matariya St. POB.11753 Matariya, Cairo, Egypt

Corresponding author: Ebrahimsamir@yahoo.com

\begin{tabular}{|c|c|c|}
\hline Article History: 21-267 & Received: 19-Jan-21 & Accepted: 09-Apr-21 \\
\hline \multicolumn{3}{|l|}{ ABSTRACT } \\
\hline $\begin{array}{l}\text { To monitor blood constitu } \\
\text { Northwestern Coast of Eg } \\
\text { Animals were divided acc } \\
\text { groups before natural mat } \\
\text { collected from all animals } \\
\text { follicular phase GLC and } \\
\text { diameter in both ovaries } \\
\text { number follicles of left or } \\
\text { In } 1^{\text {st }} \text { trimester of pregnan } \\
\left(1^{\text {st }} \text { and } 2^{\text {nd }} \text { trimesters) we }\right. \\
\text { ALP, HP and SOD and pc } \\
\text { affected (P<0.05). SOD a } \\
\text { negatively with } \mathrm{P}_{4} \text { and PF } \\
\text { values of hormonal, blood }\end{array}$ & $\begin{array}{l}\text { and hormonal profiles in dromedary she-camels at } \\
\text { twenty-four she-camels, aged } 7-10 \text { years were used } \\
\text { ing estrous behavior and ultrasound scans of ovarian } \\
\text { Pregnancy was diagnosed } 30 \text { days after mating by } \mathrm{u} \\
\text { ing estrus and non-estrus and monthly during gestat } \\
\text { evels decreased }(\mathrm{P}<0.05) \text {. Levels of } \mathrm{E}_{2} \text { and PRL incre } \\
\text { eased }(\mathrm{P}<0.05) \text { in estrus group. Cyclic status correl } \\
\text { (TLO) and diameter follicles of left ovary (DLO) an } \\
\text { GLC levels decreased. Higher }(\mathrm{P}<0.05) \text { activity of } \mathrm{A} \\
\text { corded. SOD and HP changed }(\mathrm{P}<0.05) \text {. Pregnancy st } \\
\text { vely with TG and ALT. During lactation, ALB, CHO } \\
\text { IP were higher }(\mathrm{P}<0.05) \text { in } 2^{\text {nd }} \text { and } 1^{\text {st }} \text { trimester, res } \\
\text { nd positively with CHOL, ALB, ALP, ALT and TA } \\
\text { chemical, antioxidant activities are necessary for dia }\end{array}$ & $\begin{array}{l}\text { ember } 2016 \text { to March } 2019 . \\
\text { s into estrus and non-estrus } \\
\text { raphy. Blood samples were } \\
\text { actation periods. During the } \\
0.05) \text {. Follicles number and } \\
\text { atively with GLC, } \mathrm{P}_{4} \text {, total } \\
\text { ely with AST, } \mathrm{E}_{2} \text { and DLO. } \\
\text { and } 3^{\text {rd }} \text { trimesters) and ALP } \\
\text { lated negatively with GLC, } \\
\text { LT, ALP, } \mathrm{P}_{4} \text { and PRL were } \\
\text { Lactation status correlated } \\
\text { clusion, the knowledge the } \\
\text { terpretation of pathological }\end{array}$ \\
\hline
\end{tabular}

Key words: Ovarian activities; Blood constituents; Antioxidants biomarkers; She Camel; Physiological statuses.

\section{(C202I IJVS - All Rights Reserved}

\section{INTRODUCTION}

In Egypt, the one-humped camel (Camelus dormedarius) is one of the important recourses for meat and milk in the economy and social life of a large sector of pastoralists in arid, semi-arid, regions in several localities especially in North Cost of Egypt and their total population are 120,000 heads (Abd El-Hamid et al. 2015). Meat of camels contributes about $6 \%$ of total red meat and enter many food industries such as meat burgers and cheese (Ibrahim and Nour 2010; Heydari et al. 2015). Milk is a good source of proteins, fat, vitamin $\mathrm{C}$ and energy. All essential nutrients found in bovine milk also exist in the camel milk and can be used to combat the hunger during drought season in arid and semi-arid-zones (Gassem et al. 2015; (Chemweno et al. 2019; Mahran et al. 202). Reproductive inefficiency in the one-humped camel is a major problem in most of herds due to late first service and induced ovulatory (nonspontaneous) nature with ovulation induced mainly by coitus (Anouassi and Tibary 2013). Additionally, short breeding period, long calving interval, long gestation period, limited breeding opportunities, late post-partum estrus and a relatively high embryonic loss reaching $35 \%$, might be the main factors attributing in low fertility in camels (Pratap et al. 2012). Blood hormones and biochemical concentrations in one- humped camel might be a potential aid in characterizing the different physiological problems and are frequently used because of their significant correlation with the nutritional status (Claypool et al. 1975). Therefore, studies about the biochemical constituents, hormonal concentrations and antioxidant enzymes activities are very important for clinicians in the field during different physiological phases including estrus cycle, pregnancy and lactation (Omidi et

Cite This Article as: El-Hamid IS, 2021. Blood constituents, antioxidant activities and hormonal profile in she-camels (Camelus dormedarius) during different physiological statuses in the Northwestern Coast of Egypt. International Journal of Veterinary Science 10(4): 247-258. https://doi.org/10.47278/journal.ijvs/2021.055 
al. 2015). However, fewer reports have been published concerning the influence of different physiological statuses on hormonal profiles, serum biochemical parameters and antioxidant status in one-humped camel under arid zones (Abd-El-Rahman et al. 2017). Generally, oxidative stress is associated with the generation of reactive oxygen species (ROS) Herrera et al. (2012) and can be produced by many factors, such as prenatal hypoxia, excessive glucocorticoid exposure, hyperketonemia, ketosis and negative energy balance (Al-Qudah 2011) and it is considered a very important tool in evaluation of fertility and development of embryos (Symonds et al. 2007; Mohebbi-Fani et al. 2012). The increasing it leads to weakness of biological and enzymatic activities, decrease secretion of steroids hormones and its receptors during estrus and pregnancy periods, thus reducing fertility in animal herds (Egbuna and Ifemeje 2017). As a consequence, the present study aimed to study the pattern of some blood biochemical constituents, hormonal profiles and oxidative stress status included total antioxidant capacity (TCA), malondialdehyde (MDA), superoxide dismutase (SOD), hydrogen peroxide (HP) and nitric oxide (NO) in onehumped camel with various physiological statuses and to set reference values to help in early prediction and diagnosis of metabolic diseases related to disturbance in oxidative stress as well as ensuring proper health in very challenging physiological state in one-humped camel.

\section{MATERIALS AND METHODS}

\section{Ethics Approval and Consent to Participate}

All ethical protocols have been followed in the conduct and preparation of this manuscript in conformity with the EU Directive for protection of experimental animals (2010/63/EU).

\section{Animals Management}

This study was carried out at Mariout Research Station (Latitude $31^{\circ} 00^{\prime} \mathrm{N}$; Longitude $29^{\circ} 47^{\prime} \mathrm{E}$ ) belonging to Desert Research Center, Egypt. Twenty-four mature onehumped non-lactating she-camels (Camelus dormedarius) aged 7-10 years with average body weights of $450 \pm 20 \mathrm{~kg}$, good body condition score $(2.5 \pm 0.4)$ arbitrary units according to (Faye et al. 2001) were used in this study from December 2016 to March 2019. The animals were housed in an open paddock throughout the experimental period. The camels were allowed to graze daily from 9:00 AM to 3:00 PM. Each animal received $4 \mathrm{~kg} / \mathrm{head} /$ day of pelleted concentrate mixture that contained $65 \%$ total digestible nutrients and $14 \%$ crude protein in addition to Egyptian clover (Trifolium alexandrinum) hay as roughage ad libitum. Fresh water was presented twice daily. Animals were examined clinically and were found to be free of any disease and physical abnormalities or reproductive disorders.

\section{Ultrasound Examination and Ovarian Activity}

Ovarian follicular dynamics in all she-camels were monitored using a Dynamic Imaging Concept MLV scanner ultrasound device (Eickemeyer Magic 5000 Digital), integrated with a dual frequency $(5.0-7.5 \mathrm{MHz})$ linear probe. The examined animals were restrained in a crush in a standing position during the sessions. The number and size of different types of follicles were recorded according to their ovarian activity into the following different ovarian phases: growing phase $(0.5 \mathrm{~cm}<$ follicle $<1.1 \mathrm{~cm})$, mature phase $(1.1 \mathrm{~cm}<$ follicle $<1.9 \mathrm{~cm})$ (Swelum and Alowaimer 2015). The females were divided according to estrous behavior and ultrasound scan into two statuses: 1. Estrus and 2. Non-estrus: before natural mating.

\section{Early Pregnancy Diagnosis}

After 30 days from natural mating, all animals were examined by ultrasonography to detect anechoic uterus, alantoic fluid and embryo proper or fetus which considered positive signs of pregnancy (Fig. 1).

\section{Reproductive Performance}

Reproductive performance including conception rate (number of conceived she-camels at day 30 evaluated by ultrasonography/ total number of she-camels $\times 100$ ), pregnancy rate (number of conceived she-camels/total number of she-camels $\times 100$ ), twinning rate (number of shecamels twining lambed/number of she-camels lamed $\times 100$ ) Survival, motility rate and sex ratio of calve camels were recorded.

\section{Blood Samples}

Blood samples were collected from jugular vein of all animals in plasma vacutainer tubes ( $\mathrm{K}_{3}$ EDTA) in early morning (07:00 AM) throughout estrus $(n=18)$ and nonestrus $(n=8)$ stages. Blood sampling started after 30 day of natural mating and continued monthly during pregnancy and lactation trimesters (first, second and third). Plasma was harvested after centrifugation at $1500 \mathrm{~g}$ for $10 \mathrm{~min}$, and then stored at $-20^{\circ} \mathrm{C}$ for later analysis.

\section{Blood Biochemical Analysis}

Commercial kits (Stanbio Laboratory, USA) were used to analyze plasma total proteins (TP, Cat. \# 0345), Albumin (ALB, Cat. \# 0285), Glucose (GLC, Cat. \# 1070), cholesterol (CHOL, Cat. \# 1010), triglycerides (TG, Cat. \# 2200) according to (Weichslbaum 1964; Scheletter and Nussel 1975; Trinder 1969; Finley et al. 1978; Young et al 1972), respectively. Alanine aminotransferases (ALT, Cat. \# 113100), aspartate aminotransferase (AST, Cat. \# 043360) and alkaline phosphatase (ALP Cat. \# 151050) were determined using colorimetric kits (Biomed Germany), according to (Henry 1964; Tietz 1976; Belfield and Goldberg 1971), respectively.

\section{Biomarkers of Antioxidant Enzymes Activities}

Antioxidants enzymes activities of total antioxidant capacity (TCA, Cat. \# TA2513), malondialdehyde (MDA, Cat. \# MD2529), superoxide dismutase (SOD, Cat. \# SD2521), hydrogen peroxide (HP, Cat. \# HP25) and nitric oxide (NO, Cat. \# NO2532) were calorimetrically assayed using commercial kits (Biodiagnostic Research, Egypt) according to previous reports (Koracevic et al. 2001; Satoh, 1978; Nishikimi et al. 1972; Aebi, 1984; Montgomery and Dymock, 1961) in order.

\section{Hormonal Assay}

Estradiol 17- $3 \quad\left(\mathrm{E}_{2}\right.$, Cat. \# MO4925-300) and progesterone $\left(\mathrm{P}_{4}\right.$, Cat. \# MO4825-300) hormones were analyzed using ELISA kits (Monobind, USA) according to 
Abraham (1974). The intra -and inter-assay CV's are 9.3 and $9.7 \%$, respectively. Triiodothyronine $\left(\mathrm{T}_{3}\right.$, Cat. \# MBS9914463) and prolactin (PRL, Cat. \# MBS089793) hormones were analyzed using specific camels ELISA kit (MyBioscience, USA). The intra-and inter-assay CV's are less than $15 \%$.

\section{Statistical Analysis}

All results were found as mean \pm SEM. The changes in ovarian activities, biochemical blood parameters, biomarkers antioxidant activities and hormonal profiles throughout experimental periods were statistically analyzed by one-way analysis of variance (ANOVA) to test the significance among means. Chi square of independence was used to analyze fertility-related parameters post parturition. The differences between means were detected by Duncan's post-hoc test. The correlations between all parameters and status were obtained by Pearson correlation coefficient. Significance was set at 5\% and data were analyzed by IBMSPSS statistics program (IBM-SPSS 2013).

\section{RESULTS}

Changes in Blood Biochemical Constituents and Hormonal Profiles During Cycle Status

Overall mean of plasma GLC was affected $(\mathrm{P}<0.05)$ during the follicular phase of the cycle status, where lower concentration was recorded during estrus status than in non-estrus. On the other hand, plasma concentrations of TP, ALB, CHOL, TG, ALT, AST and ALP in addition to antioxidant enzymes activities including TCA, MDA, SOD, HP and NO did not differ significantly (Table 1).

Concerning sexual hormones, the present findings demonstrated that overall means of $\mathrm{E}_{2}$ levels were higher $(\mathrm{P}<0.05)$ in estrus than non-estrus during follicular phase of the cycle status. Moreover, plasma PRL, concentrations increased $(\mathrm{P}<0.05)$ in estrus compared with non-estrus during follicular phase of the cycle status. On contrarily, plasma $\mathrm{P}_{4}$ level decreased $(\mathrm{P}<0.05)$ in estrus compared with non-estrus during the follicular phase of the cycle status. On the other hand, overall mean of plasma $\mathrm{T}_{3}$ concentration were not significantly affected throughout follicular phase of the cycle status (Fig. 2).

\section{Changes in Ovarian Follicular Activities}

The results showed that overall means of total number follicles in both ovaries (left, TLO and right, TRO) increased $(\mathrm{P}<0.05)$ in estrus stage compared with nonestrus stage. Furthermore, overall means of diameter follicles in both ovaries (left, DLO and right, DRO) increased $(\mathrm{P}<0.05)$ in estrus compared with non-estrus stage during the follicular phase of the cycle status (Table 2; Fig. 3). There were clearly negative correlations $(\mathrm{P}<0.05)$ between cyclic status and each of GLC, $\mathrm{P}_{4}$, TLO and DLO ( $\mathrm{r}=-0.78,-0.81,-0.92$ and -0.79 , respectively). On contrarily, positive correlations $(\mathrm{P}<0.05)$ were recorded between cyclic status and level of AST, $E_{2}$ and DLO ( $\mathrm{r}=0.68,0.93$, and 0.84 , respectively).

\section{Reproductive Efficiency}

Conception and pregnancy rates were recorded $77.22 \%$. However, twining rate recorded $7.96 \%$. The survival rate of calve camels recorded $85.71 \%$, while
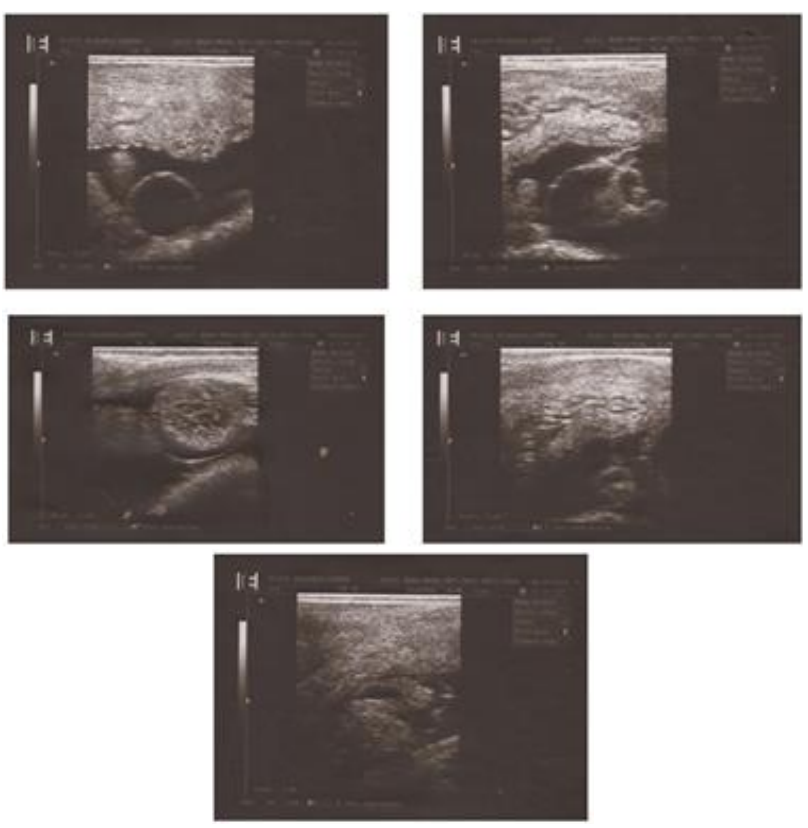

Fig. 1: Trans-rectal ultrasonic images for pregnancy after 30 days of natural mating in one-humped she-camels during early pregnancy stage.
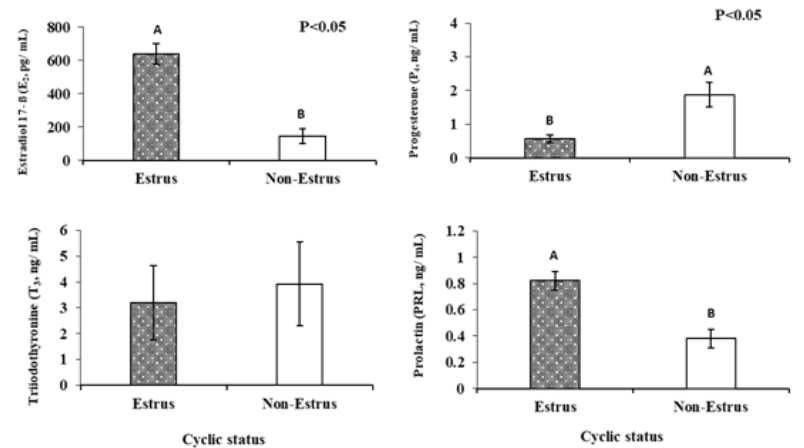

Fig. 2: Changes in plasma hormonal profiles in one-humped she camels during cyclic status in the North western Coast of Egypt.

mortality rate of calve camels was $14.28 \%$. Of the 14 calve camels born of she-camels $42.9 \%$ males vs. $57.1 \%$ females were recorded (Fig. 4 and 1).

\section{Changes in Blood Biochemical Constituents and Hormonal Profiles during Pregnancy Period}

Plasma TP, ALB concentrations were not affected by pregnancy period, while plasma GLC level was significantly affected, the lowest $(\mathrm{P}<0.05)$ value was recorded in first trimester, then increased gradually in second and third trimesters of pregnancy. Overall means of plasma CHOL and TG concentrations were not significantly changed during different pregnancy trimesters. Plasma level of ALT activity was higher $(\mathrm{P}<0.05)$ in second and third trimesters than first trimester of pregnancy. Contrariwise, plasma level of ALP activity was higher $(\mathrm{P}<0.05)$ in first and second trimesters compared with third trimester of pregnancy. While value of AST activity did not differ significantly among different pregnancy trimesters (Table 3).

Overall means of antioxidant enzymes activities included TCA, MDA and NO levels did not differ significantly among different pregnancy periods. However, 

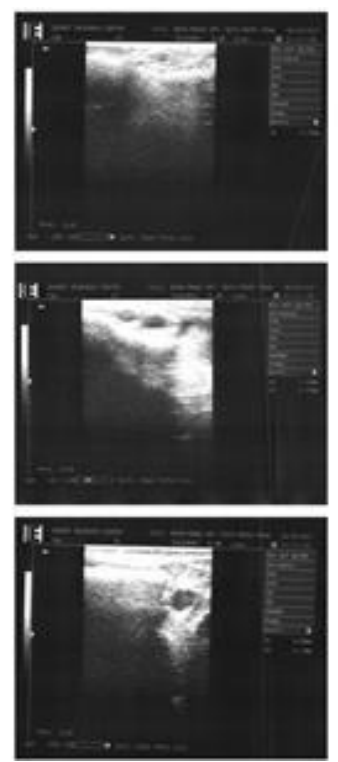

B
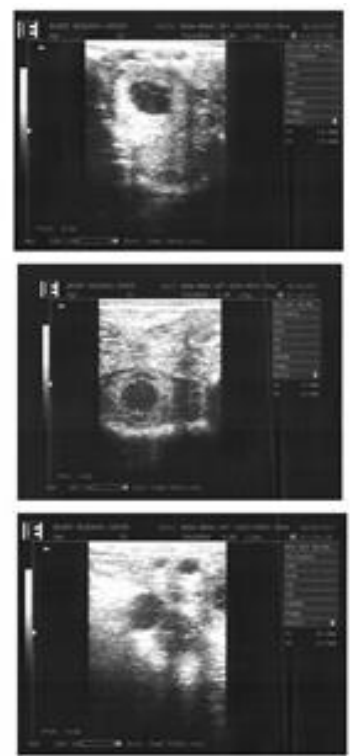

c
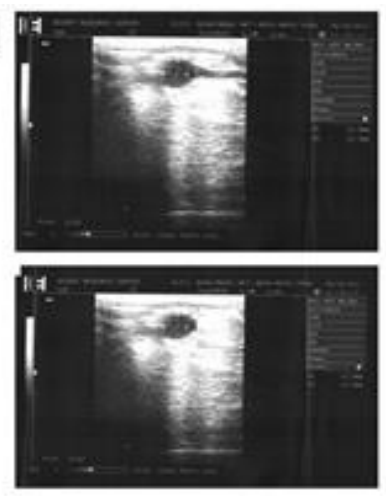

Fig. 3: Ultrasonography monitoring of ovarian activity in one-humped she-camels during cyclic status [A] small follicles [B] diameter of dominant follicles on lift ovary (DLO), $[\mathrm{C}]$ diameter of dominant follicles on right ovary (DRO), prior to natural mating.

Table 1: Changes in plasma biochemical constituents, antioxidant enzymes activities in one-humped she-camels during cyclic status in the North western Coast of Egypt

\begin{tabular}{lcc}
\hline Items & \multicolumn{2}{c}{ Cyclic status } \\
\hline Blood biochemical parameters & Estrus & Non-Estrus \\
\hline Total protein (TP, g/dL) & $6.01 \pm 0.08$ & $6.06 \pm 0.12$ \\
Albumin (ALB, g/dL) & $4.06 \pm 0.05$ & $3.97 \pm 0.07$ \\
Glucose (GLC, mg/ dL) & $97.56 \pm 7.07^{\mathrm{B}}$ & $118.45 \pm 3.86^{\mathrm{A}}$ \\
Cholesterol (CHOL, mg/ dL) & $1.03 .24 \pm 1.54$ & $107.88 \pm 4.48$ \\
Triglycerides (TG, mg/ dL) & $85.83 \pm 2.20$ & $89.69 \pm 4.79$ \\
Alanine aminotransferase (ALT, IU/L) & $68.06 \pm 6.36$ & $78.96 \pm 11.17$ \\
Aspartate aminotransferase (AST, IU/L) & $182.54 \pm 4.85$ & $171.97 \pm 2.58$ \\
Alkaline phosphatase (ALP, IU/L) & $23.26 \pm 3.11$ & $23.80 \pm 1.05$ \\
Antioxidant enzymes activities & & \\
Total antioxidant capacity (TCA, mM/L) & $0.67 \pm 0.09$ & $0.77 \pm 0.06$ \\
Malondialdehyde (MDA, nM/mL) & $5.15 \pm 0.14$ & $5.56 \pm 0.38$ \\
Superoxide dismutase (SOD, U/mL) & $5.75 \pm 0.33$ & $6.47 \pm 0.28$ \\
Hydrogen peroxide (HP, mM/L) & $0.14 \pm 0.01$ & $0.15 \pm 0.04$ \\
Nitric oxide (NO, $\mu \mathrm{M} / \mathrm{L})$ & $23.32 \pm 1.27$ & $26.05 \pm 2.06$ \\
\hline
\end{tabular}

A-B Values (Mean \pm SE) within the same row with different letters differ significantly $(\mathrm{P}<0.05)$.

Table 2: Changes in ovarian activities in one-humped she-camels during cyclic status in the North Western Coast of Egypt

\begin{tabular}{lcc}
\hline Items & \multicolumn{2}{c}{ Cyclic status } \\
\hline Follicles number & Estrus & Non-Estrus \\
\hline Total follicles of lift ovary (TLO) & $3.20 \pm 0.20^{\mathrm{A}}$ & $1.20 \pm 0.20^{\mathrm{B}}$ \\
Total follicles of right ovary (TRO) & $2.00 \pm 0.44^{\mathrm{A}}$ & $1.20 \pm 0.58^{\mathrm{B}}$ \\
Follicles diameter (cm) & & \\
Diameter follicles of lift ovary (DLO) & $2.03 \pm 0.43^{\mathrm{A}}$ & $0.59 \pm 0.07^{\mathrm{B}}$ \\
Diameter follicles of right ovary (DRO) & $1.22 \pm 0.12^{\mathrm{A}}$ & $0.40 \pm 0.06^{\mathrm{B}}$ \\
\hline
\end{tabular}

$\overline{A-B}$ Values (Mean \pm SE) within the same row with different letters differ significantly $(\mathrm{P}<0.05)$.

value of SOD was higher in first more than second trimester, while the lowest value was recorded in third trimester of pregnancy period. Value of HP was $(\mathrm{P}<0.05)$ higher in first trimester compared with second or third trimesters of pregnancy (Table 3).

Our results showed that overall means of plasma $E_{2}$ was not significantly affected by different trimesters of pregnancy. The lowest value was recorded in first trimester while higher values were recorded in second and third trimesters of pregnancy. This trend was reversed in the $\mathrm{P}_{4}$ level where the lowest value was recorded in third trimester. On the other hand, plasma $\mathrm{T}_{3}$ concentration did not differ significantly among pregnancy trimesters. The lower values were recorded in second and third trimesters while the highest value was recorded in first trimester of pregnancy. Overall means of plasma PRL was nonsignificantly affected by pregnancy. Plasma PRL level was started from $(0.72 \pm 0.15 \mathrm{ng} / \mathrm{mL})$ in first trimester and continue to increase slightly during second and third trimesters of pregnancy $(1.02 \pm 0.10$ and $1.20 \pm 0.25 \mathrm{ng} / \mathrm{mL})$ respectively (Fig. 5).

Negative correlations $(\mathrm{P}<0.05)$ were recorded between pregnancy status and levels of GLC, ALP, HP and SOD $(\mathrm{r}=-0.39,-0.37,-0.42$ and -0.83 , respectively). While, positive correlations $(\mathrm{P}<0.05)$ were noted in TG and ALT levels ( $r=0.28$ and 0.36 , respectively). 
Int J Vet Sci, 2021, 10(4): 247-258.

Table 3: Changes in plasma biochemical constituents, antioxidant enzymes activities and hormonal profiles in one-humped she-camels during pregnant period in the North Western Coast of Egypt (Mean \pm SE)

\begin{tabular}{lccc}
\hline Items & \multicolumn{3}{c}{ Trimesters of Pregnancy } \\
\hline Blood biochemical parameters & $1^{\text {st }}$ Trimester & $2^{\text {nd }}$ Trimester & $3^{\text {rd }}$ Trimester \\
\hline Total protein $(\mathrm{TP}, \mathrm{g} / \mathrm{dL})$ & $5.63 \pm 0.10$ & $5.91 \pm 0.19$ & $5.82 \pm 0.15$ \\
Albumin (ALB, g/dL) & $4.54 \pm 0.11$ & $4.68 \pm 0.16$ & $4.35 \pm 0.12$ \\
Glucose (GLC, mg/ dL) & $103.53 \pm 4.63^{\mathrm{B}}$ & $123.91 \pm 6.31^{\mathrm{AB}}$ & $134.61 \pm 11.51^{\mathrm{A}}$ \\
Cholesterol (CHOL, mg/ dL) & $125.67 \pm 4.66$ & $122.98 \pm 3.50$ & $122.21 \pm 5.62$ \\
Triglycerides (TG, mg/ dL) & $89.05 \pm 2.82$ & $95.21 \pm 2.42$ & $96.92 \pm 1.95$ \\
Alanine aminotransferase (ALT, IU/L) & $68.96 \pm 2.32^{\mathrm{B}}$ & $83.16 \pm 3.72^{\mathrm{A}}$ & $84.65 \pm 4.19^{\mathrm{A}}$ \\
Aspartate aminotransferase (AST, IU/L) & $178.20 \pm 4.69$ & $179.54 \pm 4.61$ & $172.00 \pm 3.16$ \\
Alkaline phosphatase (ALP, IU/L) & $31.13 \pm 1.72^{\mathrm{A}}$ & $31.19 \pm 2.22^{\mathrm{A}}$ & $21.95 \pm 2.55^{\mathrm{B}}$ \\
Antioxidant enzymes activities & & & \\
Total antioxidant capacity (TCA, mM/L) & $0.62 \pm 0.04$ & $0.61 \pm 0.02$ & $0.61 \pm 0.03$ \\
Malondialdehyde (MDA, nM/mL) & $5.35 \pm 0.33$ & $5.52 \pm 0.18$ & $5.82 \pm 0.27$ \\
Superoxide dismutase (SOD, U/mL) & $5.92 \pm 0.34^{\mathrm{A}}$ & $4.42 \pm 0.27^{\mathrm{B}}$ & $1.7 \pm 0.15^{\mathrm{C}}$ \\
Hydrogen peroxide (HP, mM/L) & $0.19 \pm 0.01^{\mathrm{A}}$ & $0.18 \pm 0.01^{\mathrm{AB}}$ & $0.16 \pm 0.01^{\mathrm{B}}$ \\
Nitric oxide (NO, $\mu \mathrm{M} / \mathrm{L})$ & $24.56 \pm 1.10$ & $23.04 \pm 0.45$ & $22.96 \pm 0.91$ \\
\hline
\end{tabular}

$\overline{\mathrm{A}-\mathrm{C}}$ Values $(\mathrm{Mean} \pm \mathrm{SE})$ within the same row with different letters differ significantly $(\mathrm{P}<0.05)$.

Table 4: Changes in plasma biochemical constituents, antioxidant enzymes activities and hormonal profiles in one-humped she-camels during lactation period in the North Western Coast of Egypt

\begin{tabular}{lccc}
\hline Items & \multicolumn{3}{c}{ Trimesters of lactation } \\
\cline { 2 - 4 } & $1^{\text {st }}$ Trimester & $2^{\text {nd }}$ Trimester \\
\hline Blood biochemical parameters & & & \\
\hline Total protein (TP, g/dL) & $5.64 \pm 0.28$ & $5.91 \pm 0.19$ & $5.83 \pm 0.12$ \\
Albumin (ALB, g/dL) & $4.13 \pm 0.13^{\mathrm{B}}$ & $4.08 \pm 0.09^{\mathrm{B}}$ & $4.43 \pm 0.11^{\mathrm{A}}$ \\
Glucose (GLC, mg/ d, L) & $97.39 \pm 5.34$ & $95.07 \pm 2.71$ & $98.01 \pm 2.65$ \\
Cholesterol (CHOL, mg/ dL) & $135.76 \pm 3.08^{\mathrm{A}}$ & $119.97 \pm 2.13^{\mathrm{B}}$ & $108.66 \pm 3.87^{\mathrm{C}}$ \\
Triglycerides (TG, mg/ dL) & $93.83 \pm 2.28^{\mathrm{A}}$ & $82.31 \pm 1.95^{\mathrm{B}}$ & $73.44 \pm 1.92^{\mathrm{C}}$ \\
Alanine aminotransferase (ALT, IU/L) & $70.88 \pm 1.93^{\mathrm{B}}$ & $96.91 \pm 2.41^{\mathrm{A}}$ & $101.46 \pm 1.06^{\mathrm{A}}$ \\
Aspartate aminotransferase (AST, IU/L) & $178.08 \pm 5.27$ & $171.07 \pm 1.64$ & $173.74 \pm 3.01$ \\
Alkaline phosphatase (ALP, IU/L) & $21.34 \pm 2.55^{\mathrm{B}}$ & $30.19 \pm 2.60^{\mathrm{A}}$ & $30.79 \pm 2.12^{\mathrm{A}}$ \\
Antioxidant enzymes activities & & & \\
Total antioxidant capacity (TAC, mM/L) & $0.59 \pm 0.02$ & $0.66 \pm 0.03$ & $0.70 \pm 0.01$ \\
Malondialdehyde (MDA, nM/mL) & $5.90 \pm 0.22$ & $6.60 \pm 0.36$ & $6.39 \pm 0.24$ \\
Superoxide dismutase (SOD, U/mL) & $1.07 \pm 0.27^{\mathrm{B}}$ & $2.48 \pm 0.57^{\mathrm{A}}$ & $1.10 \pm 0.10^{\mathrm{B}}$ \\
Hydrogen peroxide (HP, mM/L) & $0.20 \pm 0.01^{\mathrm{A}}$ & $0.16 \pm 0.01^{\mathrm{B}}$ & $0.17 \pm 0.01^{\mathrm{B}}$ \\
Nitric oxide (NO, $\mu \mathrm{M} / \mathrm{L})$ & $24.62 \pm 0.72$ & $23.59 \pm 0.71$ & $24.65 \pm 0.69$ \\
\hline
\end{tabular}

${ }_{\mathrm{A}-\mathrm{C}}$ Values (Mean $\left.\pm \mathrm{SE}\right)$ within the same row with different letters differ significantly $(\mathrm{P}<0.05)$.

\section{Changes in Blood Biochemical Constituents and Hormonal Profiles during Lactation Period}

Mean value of plasma TP and GLC levels did not differ significantly among different trimesters of lactation periods. However, plasma ALB value increased $(\mathrm{P}<0.05)$ in third trimester compared with first and second trimesters of lactation. Furthermore, plasma CHOL concentration increased $(\mathrm{P}<0.05)$ in first trimester and decreased gradually through second and third trimesters of lactation. The same trend was observed for of plasma TG concentrations. Mean value of alanine ALT activity was higher $(\mathrm{P}<0.05)$ in second and third trimesters of lactation than in the first trimester. The activity of AST was not affected by lactation periods. Mean value of ALP activity was higher $(\mathrm{P}<0.05)$ in second and third trimesters of lactation than during the early stage (Table 4).

Mean values of TCA and MDA were not affected with trimesters of lactation, while mean value of SOD was higher $(\mathrm{P}<0.05)$ in second $(2.48 \pm 0.57 \mathrm{U} / \mathrm{mL})$ more than first $(1.07 \pm 0.27 \mathrm{U} / \mathrm{mL})$ or third $(1.10 \pm 0.10 \mathrm{U} / \mathrm{mL})$ trimesters of lactation period. Men value of HP was $(\mathrm{P}<0.05)$ higher in first trimester, then declined in second and third trimesters of lactation period. Also, the results showed that mean value of HP was not affected by different trimesters of lactation period (Table 4).

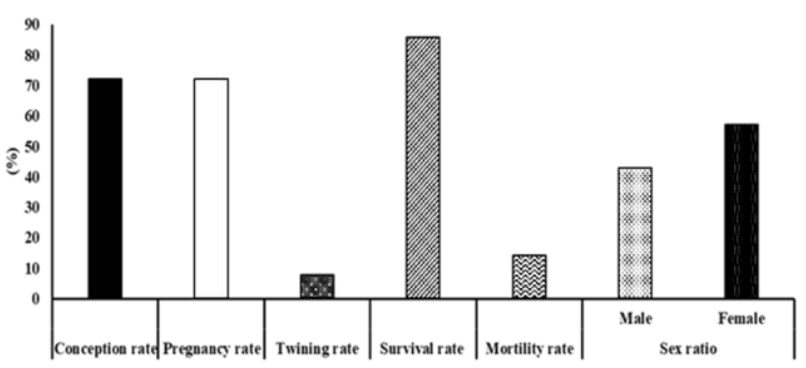

Fig. 4: Reproductive performance of She-camels following natural mating in the North Western Coast of Egypt.

Overall means of plasma $\mathrm{E}_{2}$ concentrations did not differ significantly among different lactation periods. Conversely, means of plasma $\mathrm{P}_{4}$ concentrations were affected $(\mathrm{P}<0.05)$ by lactation periods. The highest concentration of progesterone was recorded in first trimester of lactation period, then declined during second and third trimesters of lactation period. Overall means of plasma $\mathrm{T}_{3}$ did not differ significantly among different lactation periods. While overall means of plasma PRL concentrations the highest $(\mathrm{P}<0.05)$ value was recorded in first trimester $(5.13 \pm 2.3 \mathrm{ng} / \mathrm{mL})$ followed by second $(1.54 \pm 0.12 \mathrm{ng} / \mathrm{mL})$ and third $(1.24 \pm 0.45 \mathrm{ng} / \mathrm{mL})$ trimester of lactation period (Fig. 6). 

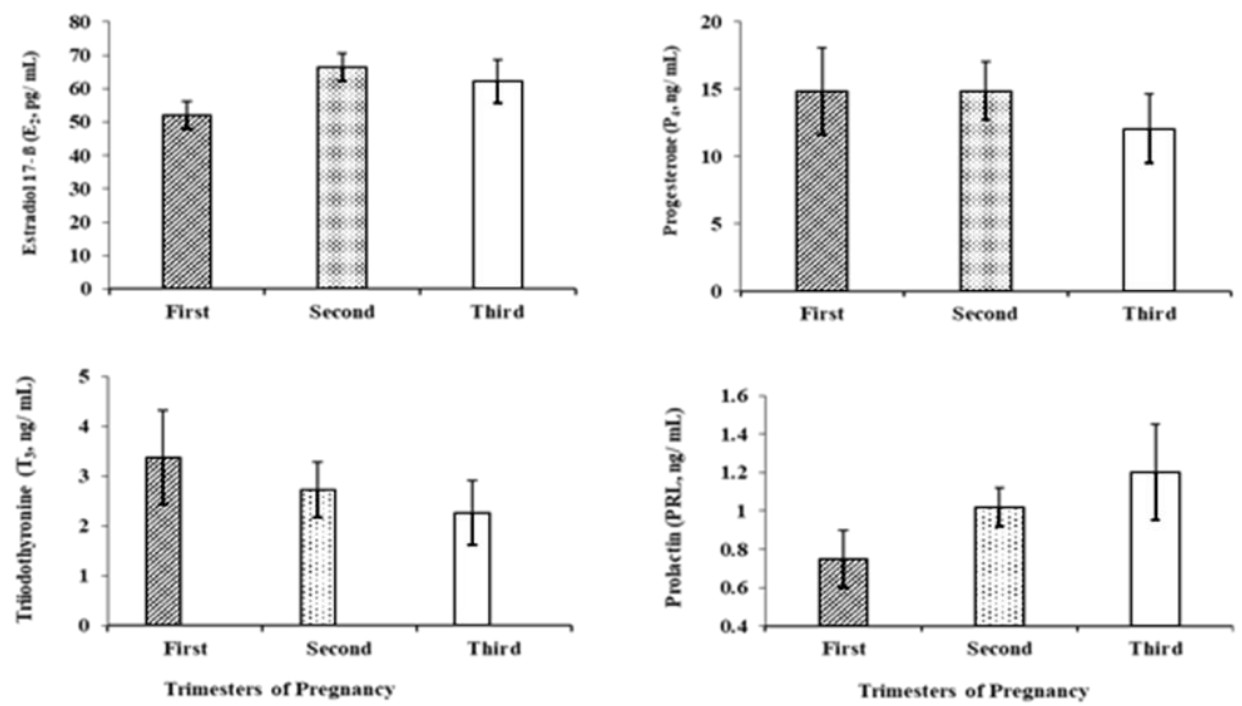

Fig. 5: Changes in plasma hormonal profiles in one-humped she-camels during pregnancy period in the North western Coast of Egypt.
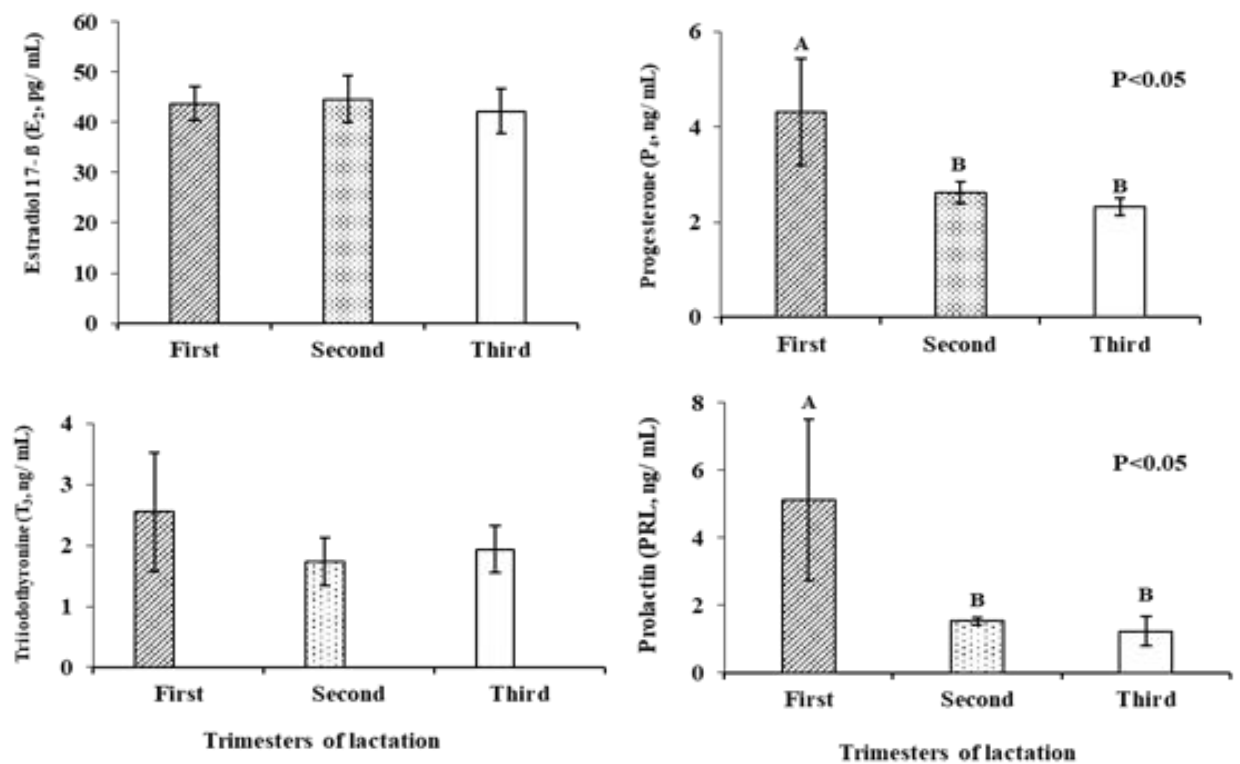

Fig. 6: Changes in plasma hormonal profiles in one-humped she-camels during lactation period in the North western Coast of Egypt.

The results showed that positive correlations $(\mathrm{P}<0.05)$ were recorded between lactation and levels of $\mathrm{CHOL}$, ALB, ALP, ALT and TAC ( $\mathrm{r}=0.26,0.30,0.28,0.70$ and 0.30 , respectively). While, negative correlations $(\mathrm{P}<0.05)$ were recorded between lactation sand level of P4 and PRL $(\mathrm{r}=-0.39$ and -0.41 respectively).

\section{DISCUSSION}

\section{Changes in Blood Biochemical Constituents and} Hormonal Profiles during Cycle Status

Our results showed that plasma concentrations of TP, ALB, CHOL, TG, ALT, AST and ALP were not significantly changed among estrus status. It is worthy of mentioning that our values were within the reference values of few available reports (Abdalmula et al. 2019; Islam et al. 2019) during cyclic stages in she-camels (Camelus Dromedarius). While GLC level decreased in estrus status, compared with non-estrus. These data are in agreement with those reported by Abd El-Hamid et al. (2015) where serum GLC concentration decreased at days 10 and 20 of induction of ovulation period in dromedary she-camels during breeding season. The same results were reported in several species, in goats, plasma GLC level decreased during ovarian dynamics and estrus activities (Rateb et al. 2019). This reduction in plasma GLC with ovarian activities and increased of $\mathrm{E}_{2}$ hormone, due to uptake GLC by ovarian tissues to accommodate ovarian activities (Rabiee and Lean 2000). These results are supported by the data presented in Fig. 2.

Also, plasma antioxidant enzymes activities including TCA, MDA, SOD, HP and NO were not affected by different cycle status. Agree with these results, (Kandiel et al. 2016) reported that no significant difference was recorded in level of biochemical markers included (SOD, GPX, MDA, NO) during estrus cycle stages in Barki sheep. Colakoglu et al. (2017) suggested that blood antioxidant enzymes activities such as GSH-Px and MDA would be useful in evaluation the fertility of dairy cows under seasonal variations. Fewer reports were presented about 
relationship between oxidative status and ovarian activity especially in camels. However, many studies were presented about relationship between oxidative status and pregnancy or per-parturient status in camels (Abd-ElRahman et al. 2017). The considered balance between generation reactive nitrogen species and elimination reactive oxygen species (ROS) is an important role in gene expression. So, it is required for every metabolic function and biological activities in mammals (Shkolnik et al. 2011). The ROS are produced as by-products of aerobic metabolism, as results of many factors such as cellular metabolites and as a response to climate changes and toxicity of the surrounding environment (Shedeed et al. 2019). ROS exert both negative and positive effects in mammalian ovaries from maturation follicles to fertilization (Fujii et al. 2005). Several factors such as macrophages, leukocytes, and cytokines, which present in the follicular fluid, are considered major sources of ROS, which are involved in follicular growth by regulating angiogenesis and maturation by increasing the metabolic function of granulosa cells and ovarian steroid biosynthesis (Du et al. 2006). They also support the LH hormone in induction ovulation (Khalifa et al. 2020). In contrast, the excessive of ROS resulting in blood flow alterations and eventual follicle rupture (Wang et al. 2017). These results are supported by the data of ovarian activities (Fig. 2 and 3) and reproductive performance (Fig. 4).

Plasma $\mathrm{E}_{2}$ concentration was significantly higher in estrus cycle compared with non-estrus cycle during the follicular phase. While plasma $\mathrm{P}_{4}$ concentrations decreased significantly in estrus cycle compared with non-estrus during the follicular phase of the cycle status. However, value of plasma $\mathrm{T}_{3}$ was not affected throughout follicular phase of the cycle status. This finding is in agreement with previous reports on dromedary camels (Ali et al. 2011; Abd El-Hamid et al. 2015) as they reported that, the increased of $\mathrm{E}_{2}$ concentration due to the found of dominant follicle size $(1.2-1.8 \mathrm{~cm})$ during mature ovarian phase (Atigui et al. 2014), the concentration of $E_{2}$ secretion is around (317.8$444.4 \mathrm{pg} / \mathrm{mL}$ ), whereas $\mathrm{P}_{4}$ concentration remains below $(1 \mathrm{ng} / \mathrm{mL})$ during the follicular phase. Additionally, in dromedary she-camels, a higher significant correlation was found between $\mathrm{E}_{2}$ levels and follicular size during mature phase. This led to exhibit behavioral estrus patterns to mating reported by Padalino et al. (2016). These results are supported by the data presented in Fig. 2.

Plasma PRL value increased during estrus cycle (Fig. 2). In cattle and ewes, plasma PRL levels higher peaks in the estrus cycle were tied in with releasing amount of luteinizing hormone (Davis et al. 1971) reported that serum PRL levels increased at 2-3-day intervals during the natural cycle. In ewe's, plasma RPL level increased during natural estrus and a positive correlation between fertility and plasma PRL level was found (Rhind et al. 1980). In mares, a significant increase in plasma PRL levels was recorded at the first ovulation during reproductive season (Besognet et al. 1995).

\section{Changes in Ovarian Follicular Activities}

In she-camels, follicular wave can be divided into three phases: 1] the growth phase: about 3 to 6 follicles grow until reaching approximately $(0.8 \mathrm{~cm})$ in diameter, 2$]$ the mature phase: where one or two growing follicles become dominant and continue to develop until the diameter reaches from $(1.2$ to $1.8 \mathrm{~cm})$, in the absence of ovulation, 3] the mature phase is followed by a regression phase, reaches in which anovulatory follicles from 2 to $4 \mathrm{~cm}$ in diameter (Monaco et al. 2015). Our ovarian data in the present study showed that total number follicles (TNF) and diameter follicles in both ovaries left and right (DLF, DRF) increased significantly during estrus cycle (Table 2). Similar results have been previously obtained in shecamels (Rawy et al. 2014) where maximum of dominant follicular diameter in the ovulatory phase was found to be $(1.82 \pm 0.2 \mathrm{~cm})$ with reach to higher production, of estrogen. These results are supported by the data of estrogen (Fig. 2). El-Harairy et al. (2010) reported that the histological examination in the left and right ovaries of the dromedary she-camel revealed that, camel's ovary showed higher activity during breeding seasons (winter) than in summer and autumn. Furthermore, (Zeidan et al. 2008) concluded that the left ovary contains (growing and mature follicles) was more active than the right one in she-camels during breeding season from December to April in Egypt.

\section{Reproductive Efficiency}

The reproductive performance in she-camels' herds is extremely low as compared with that of other domestic livestock due to several factors such as age, breeds, infectious diseases, management, long gestation period and nutrition (Bakheit et al. 2016). In this study, the overall of conception/ pregnancy rates were recorded $77.22 \%$. However, the twining and survival rates of calve camels were recorded 7.96 and $85.71 \%$, respectively. While, the mortality rate of calve camels was recorded $14.28 \%$. The sex ratio of calve camels was $42.9 \%$ males vs. $57.1 \%$ females (Fig.4). Agreement with these results, (Mostafa et al. 2018; Ali et al. 2018) they reported that the conception and pregnancy rates were 79.8 and $76.2 \%$ in herd camels, in order. On the other hand, (Mohammed and Al-Mutairi 2012) reported that the overall mean of conception rate ranged from 47 to $57.5 \%$ during breeding season. Quzy et al. (2013), reported that pregnancy rates were recorded $65 \%, 61 \%$ when hormonal protocols Ovsynch and PG were applied during the natural breeding season in she-camels. The average of mortality rate of calve camels were recorded between 13.5-27\% reported by (Kaufmann 2005). Three cases of twin pregnancies were recorded in 30.0 gravid uteri of slaughtered camels (Tinson et al. 2001), this was due to multiple ovulations (Khalifa 2012).

\section{Changes in Blood Biochemical Constituents and Hormonal Profiles during Pregnancy Period}

Our results showed that overall of plasma TP, ALB, CHOL, TG and AST were not affected by pregnancy trimesters. These results were consistent with previous results in pregnant she-camels (Abd El-Hamid et al. 2015; Abd-El-Rahman et al. 2017).

Plasma GLC concentration lowered significantly in first trimester compared with second and third of pregnancy period. These data are in agreement with those reported by (Ayoub et al. 2003) in pregnant she-camels. The decrease in plasma GLC of pregnant she-camels may be due to highly bearing embryo consumption which reflected the greater demands from glucose and uptake it from muscle and fat (Firat and Ozpmnar 2002). 
In the present study, plasma level ALT elevated significantly in second and third trimester of pregnancy period, also value of ALP was significant higher in first and second of pregnancy (Table 3). Tharwat et al. (2015) reported that serum activity of ALT and ALP in the female camels increased significantly during $2^{\text {rd }}$ and $3^{\text {rd }}$ trimesters of pregnancy. Similar findings were reported in cows (Tharwat et al. 2012) during pregnancy stages. This increase in transaminases activities are not considered a pathological condition, but rather is due to impairment in some muscle and liver cells due to rapid gluconeogenesis associated with pregnancy (Saeed et al. 2009). In our study, overall means of SOD and HP enzymes activities were significant higher in first trimester but declined in second and third trimesters of pregnancy. These results agreed with (Garrel et al. 2010; Mohebbi-Fani et al. 2012) reported that SOD and HP levels declined gradually during placental growth in pregnant ewes. The SOD and HP are a major antioxidant defense of reactive oxygen species (ROS) in both animal and human. Higher $\mathrm{SOD}_{2}$ and $\mathrm{HP}$ activities lead to more of production of $\mathrm{H}_{2} \mathrm{O}_{2}$ and propagation of ROS in the mitochondria and cytoplasm which leads to imbalance between production of ROS and antioxidant systems, thus the occurrence of pregnancy disorders (AlGubory et al. 2010).

Overall means of TCA, MDA and NO levels were not affected by different trimesters of pregnancy. Agree with our results, Abd-El-Rahman et al. (2017) concluded that TCA values did not differ between $1^{\text {st }}$ and $2^{\text {nd }}$ trimesters of pregnancy, while MDA values evaluated during the three trimesters of pregnancy in dromedary She-Camel. In dairy cows, Sharma et al. (2011) reported that the value of TCA enzyme activity did not changed among late pregnancy and early lactation stages. Castillo et al. (2006) concluded that no changed was recorded in MDA levels in dairy cows during late pregnancy. In this study, the balance in producing malondialdehyde and nitric oxide refers to the efficiency consumption of oxygen and neutralization of free radicals and this can be linked to improve of total antioxidant capacity.

Plasma $\mathrm{E}_{2}$ was markedly affected by different pregnancy period, where the lowest value was in first trimester, and then increased with the advanced of pregnancy. Agreement with our results, Abo El-Maaty et al. (2015) reported that plasma $E_{2}$ concentration increased in pregnant camels and is referred to the capacity for estradiol production by the trophoblast (Wooding et al. 2003). Plasma $E_{2}$ is a good indicator to predict the time of parturition in she-camel.

On the other hand, the trend of $\mathrm{P}_{4}$ level was significantly affected by pregnancy where the higher values were recorded in first and second trimesters, and started to decline during third trimester of pregnancy. Serur et al. (2006) noted a steady increase in plasma $\mathrm{P}_{4}$ during early and mid-gestation, followed by a decrease in late gestation returning to basal levels during early post-partum period. Furthermore, Agrawal et al. (1996), observed higher values of progesterone ranging from 1.0 to $7.5 \mathrm{ng} / \mathrm{ml}$ on day 7 post-mating. They concluded that this elevation in progesterone concentration occurred as a consequence of ovulation and development of CL in camels. Similarly, Skidmore (2005) reported that serum progesterone levels, in pregnant camel, were higher in early (2.83 to
$6.89 \mathrm{ng} / \mathrm{mL})$ and the last month of pregnancy (7.4 to $9.2 \mathrm{ng} / \mathrm{mL})$.

Plasma $\mathrm{T}_{3}$ concentration was not significantly changed among different pregnancy trimesters. The higher value was recorded in first trimester, and there were slight declines in second and third trimesters of pregnancy. Our findings are in agreement with those reported by (Abo ElMaaty et al. 2015; Abd-El-Rahman et al. 2017) where that value of $\mathrm{T}_{3}$ was higher in $1^{\text {st }}$ trimester and gradually decreased at, $2^{\text {nd }}$ and $3^{\text {rd }}$ trimesters in pregnant she-camels. Thyroid gland plays an important role in many metabolic activities (Khan et al. 2014) such as lipoprotein metabolism (Duntas 2002), and its hormonal activity has a role crucial to sustain the reproductive performance, healthy pregnancy, and brain development in fetus of animals (LaFranchi et al. 2005). Reduction of thyroid hormones during pregnancy could be due to, increase their production of thyroid-binding globulin from (TBG) hepatocytes. High TBG with high estradiol concentration during pregnancy lead to a reduction of thyroxin hormones during pregnancy of camels (Leung and Farwell 2010).

Overall means of plasma PRL was no significantly affected by pregnancy period where it increased steadily from first trimester and continued in second and third trimester of pregnancy. These results were in agreement with previous results in she-camels (Ibrahim et al. 2017). Dopamine is known to regulate the secretion of PRL through a long feedback mechanism (Gill-Sharma 2009) and is particularly important for females after labor (Delitala, 2009). High level of $\mathrm{E}_{2}$ leads to stimulate the growth of pituitary and promote (PRL) release (Perez 1986).

\section{Changes in Blood Biochemical Constituents and Hormonal Profiles during Lactation Period}

Mean value of plasma TP did not differ significantly among lactation periods. However, plasma ALB level was significantly higher in third trimester of lactation period. Dowelmadina et al. (2012) and Joshi et al. (2017) reported that total TP and GLC concentrations were similar in all three stages of lactation (Early-mid-late), while the ALB concentration was significant increased from early to late stage of lactation period in camels. Plasma proteins play a crucial role in maintaining homeostasis, and a decline in their concentration may suggest imply fat infiltration into the liver (Faramarzian et al. 2016). In this study protein fractions levels recorded during lactation stages may reflect the more catabolism of protein for milk synthesis and providing immunoglobulins, additionally the albumin has the water property and higher incentive in camels, likely, show particular adjustment for the desert environment (Salman and Afzel 2004).

Abd El-Salaam et al. (2018) concluded that serum GLC concentration was not significantly changed at 2 months before calving and $1^{\text {st }}, 2^{\text {nd }}$ and $3^{\text {rd }}$ months of postpartum period in Maghrebian she-camels.

Results of the present study indicated that lipid metabolites including CHOL and TG concentrations increased in first trimester and gradually decline in second and third trimesters of lactation period. Similar results were previously observed in lactating camels (Abd El-Salaam and Arafa 2018), in dairy cows (Kessler et al. 2014). In this study, the rise of CHOL and TG concentrations at first of 
lactation period are most likely due to the increasing need for synthesis of milk fat and milk fat content such as long chain fatty acids and chylomicrons (Faramarzian et al. 2016), in addition to the need of the ovaries for synthesis of steroid hormones (Turk et al. 2015).

The present study revealed that ALT activity increased significantly during second and third trimesters of lactation period. However, AST activity was not affected. Transaminases were reported as essential enzymes in biological processes due to their role in catabolism and biosynthesis of amino acids. They are found mainly intramuscularly, in liver and heart muscles, and to a certain degree in skeletal muscles, kidney and red blood cells. The change in their level reflects the function of these organs, and for that reason they are specific indicator of liver dysfunction (Harper and Redwell 1977). In accordance with the present results, Khalifa (2012) reported that plasma ALT enzyme activity increased during post-partum months in camels, while AST enzyme activity did not change. Saeed et al. (2009) reported that the changes in transaminases might be due to gluconeogenesis enhancement in some muscle and liver cells, but the observed changes in plasma ALT activity in this study are within in normal range of camel (Abd El-Hamid et al. 2015). Also, in this study plasma ALP activity increased significantly during second and third trimesters of lactation period. Agree with those results, Tharwat et al. (2015) reported that ALP enzymes activity increased after parturition in camels. The increase in plasma ALP activity may also be explained by the stress of lactation and increased placental production of this enzyme during pregnancy period (Tharwat et al. 2015).

Mean values of TCA, MDA and HP activities did not differ among different lactation stages, while mean value of SOD concentrations was higher in the mid stage compared with early and late stages of lactation period. Moreover, value of HP activity was significant higher in early stage. Konvicna et al. (2015) and Shedeed et al. (2019) recorded that SOD and HP concentrations were significantly higher during lactation period. The oxidative stress continues to be a problem in lactating animals and it causes many other diseases such as mastitis, retention of fetal membranes due to several factors such as calving which has a greater effect on this imbalance (Sordillo et al. 2007), in addition to unbalance of diets content from the minerals and vitamins (Sharma et al. 2011). This leads to activate some enzymes (protein kinase $\mathrm{C}$, xanthine oxidase, cyclooxygenase, ascorbic acid oxidase, lipoxygenase, ATPase, and cAMP phosphodiesterase), which lead to the production of ROS species (Kurek-Gorecka et al. 2014). The performance of lactating animals can be optimized to a certain extent by supplementing diets with optimal levels of neutral additives to enhance the antioxidant defense mechanism (Sordillo et al. 2009).

The present results showed that levels plasma $E_{2}$ and $\mathrm{T}_{3}$ levels did not differ among different lactation period, while plasma $\mathrm{P}_{4}$ concentrations were significantly affected. The higher concentration of $\mathrm{P}_{4}$ was recorded in first trimester, and then declined through second and third trimesters of lactation period. These findings are in agreement with previous reports in camels (Kamoun and Jemmali 2014), where $\mathrm{P}_{4}$ level decreased sharply at parturition and continue to decline with advanced of lactation. It seems that this characteristic drop of $\mathrm{P}_{4}$ at parturition may be due to the destruction of the corpus luteum of pregnancy as a sequel of luteolysis. In addition, the lactation status significantly effects on decrease of serum $\mathrm{P}_{4}$ level (El-Zahar et al. 2017).

The same trend was found in the levels of plasma PRL. The prolactin hormone secreted by the anterior pituitary plays an important role in establishment of lactation and milk production, where it works on promoting the transcription of casein mRNA, stimulating synthesis of alpha-lact albumin and increasing lipoprotein lipase activity in the mammary gland. Prolactin exists in three heterogenic forms, varying in biological activity, the monomer is a principal consider active biological form, represents the greatest quantity from prolactin. The level of prolactin increases during late pregnancy and decreases with advance of lactation period as result to the proportion of the monomer in circulation decreases in response to selective uptake it by the mammary gland, In addition to a shift in the ratio of monomer active to less active forms (Ostrom, 1990).

\section{Conclusion}

In conclusion, the present study brings knowledge on the values of hormonal, blood biochemical and biomarkers of antioxidants parameters in she-camels (Camelus dormedarius) throughout various physiological statuses such as estrus, pregnancy and lactation. These values are necessary for diagnostic interpretation of pathological, and might have important roles in adjusting the different functions throughout different physiological statuses under arid environmental conditions. Also, from the aforementioned results we can get the knowledge of the pattern of ovarian dynamics and critical reproductive periods with oxidative stress and reproductive performance for she-camel herds.

\section{Acknowledgement}

The authors are thankful to Prof. Dr. Yousri M. Shaker and Dr. Eman A. Noman, for their support during implementation of the study.

\section{Authors' Contributions}

Conceptualization: Ibrahim S Abd El-Hamid. Conduct all stages the research and blood plasma biochemical analysis in DRC complex laboratories and statistical analysis of the results and drafting the manuscript.

\section{REFERENCES}

Abd El-Hamid IS, Zaghloul AA, El-Bahrawy KA and ElZarkouny SZ, 2015. Influence of progestin source on some blood biochemical constituents of dromedary she-camels during induction of ovulation in the north western coast of Egypt. Egyptian Journal of Animal Production 52: 63-70. https://dio.org/10.21608/ejap.2015.93640

Abd El-Salaam AM and Arafa MM, 2018. Post-partum hematological, biochemical, mineral and hormonal changes in blood of Maghrebian she-camels with different parity order under Egyptian condition. IOSR Journal of Agriculture and Veterinary Science 11: 68-78. https://doi.org/10.9790/ 2380-1102016878

Abdalmula AM, Benashour MF, Shmela ME, Alnagar FA, Abograra IM and Buker AO, 2019. Blood profile in normal 
one humped dromedary (Camelus Dromedarius) camels in Libya. Part 3: Effect of sex variation on biochemical and haematological blood profile. International Journal of Science Basic and Applied Research 48: 9-24.

Abd-El-Rahman Howida MA, Ibrahim Maha A and Elmetwaly HA, 2017. Hormonal profile, antioxidant status and some biochemical parameters during pregnancy and periparturient period in dromedary she camel. Egyptian Journal of Veterinary Science 48: 81-94. https://doi.org/10.21608/ ejvs.2017.2040.1022

Abo El-Maaty Amal M, Elgabry MAI, Gabr Faten I and Ezzo Omima H, 2015. Thyroid and sex hormones in serum of pregnant and non-pregnant camels (Camelus dormedarius). Egyptian Journal of Veterinary Science 45: 41-53. https://doi.org/ 10.21608/ejvs.2015.808

Abraham GE, 1974. Ovarian and adrenal contribution to peripheral androgens during the menstrual cycle. Journal of Clinical Endocrinology \& Metabolism 39: 340-346. https://doi.org/10.1210/jcem-39-2-340

Aebi H, 1984. Catalase in vitro. Methods in Enzymology 105: 121-126. https://doi.org/10.1016/S0076-6879(84)05016-3

Agrawal SP, Rai AK, Vays S and Khanna ND, 1996. Augmentation of early reproduction through hormonal therapy in camel heifers. Intentional Journal of Animal Science 11: 361-363.

Al-Gubory K, Garrel C, Delatouche L, Heyman Y and ChavattePalmer P, 2010. Antioxidant adaptive responses of extraembryonic tissues from cloned and non-cloned bovine conceptuses to oxidative stress during early pregnancy. Reproduction 140: 175-181. https://doi.org/10.1530/REP10-0172

Ali S, Ahmad N, Akhtar N, Rahman ZU and Ahmad M, 2011. Hormonal profiles in the serum and follicular fluid of female camel (Camelus dromedarius) during the peak and the low breeding season. Pakistan Veterinary Journal 31: 331-335.

Ali A, Derar D, Alsharari A, Khalil R, Almundarij TI, ALBoti Y and Al-Sobayil F, 2018. Factors affecting reproductive performance in dromedary camel herds in Saudi Arabia. Tropical Animal Health and Production 50: 1155-1160. https://doi.org/10.1007/s11250-018-1545-3

Al-Qudah KM, 2011. Oxidant and antioxidant profile of hyperketonemic ewes affected by pregnancy toxemia. Veterinary Clinical Pathology 40: 60-65. https://doi.org/ 10.1111/j.1939-165X.2011.00284.X

Anouassi A and Tibary A, 2013. Development of a large commercial camel embryo transfer program: 20 years of scientific research. Animal Reproduction Sciences 136: 211221. https://doi.org/10.1016/j.anireprosci.2012.10.012

Atigui M, Hammadi M and Khorchani T, 2014. Effects of oestrus on milk yield and composition in Tunisian Maghrebi camels (Camelus dromedarius). Emirates Journal of Food and Agriculture 25: 291-295. https://doi.org/10.9755/ejfa.v25i4. $\underline{15497}$

Ayoub MA, El-Khouly M and Mohamed TM, 2003. Some hematological and biochemical parameters and steroids hormone levels in the one-humped camels during different physiological conditions. Emirates Journal of Food and Agriculture 15: 44-55. https://doi.org/10.9755/ejfa.v15i1. $\underline{5281}$

Bakheit SA, Faye B, Ahmed AI and Elshafei IM, 2016. Effect of farming system on camels calving interval in Western Sudan. Turkish Journal of Food and Agriculture Sciences 4: 418423. https://doi.org/10.24925/turjaf.v4i5.418-423

Belfield A and Goldberg DM, 1971. Colorimetric determination of alkaline phosphatase activity. Enzyme 12: 561-566.

Besognet B, Hansen BS and Daels PF, 1995. Prolactin secretion during the transitional phase and the relationship to onset of reproductive season in mares. Biology of Reproduction 52: 459- 467. https://doi.org/10.1093/biolreprod/52.mono graph series 1.459
Castillo C, Hernandez J, Valverde I, Pereira V, Sotillo J, Alonso ML and Benedito JL, 2006. Plasma malonaldehyde (MDA) and total antioxidant status (TAS) during lactation in dairy cows. Research in Veterinary Science 80: 133-139. https://doi.org/ 10.1016/j.rvsc.2005.06.003

Chemweno VJ, Gitao CG, Gachohi JM, Soi RK, Ndungu EK, Khalif A and Omani RN, 2019. PPR in camels: Seroprevalence and socio-economics. International Journal of Veterinary Science 8: 84-88.

Claypool DW, Adams FW, Pendell HW, Hart-mann NA and Bone JF, 1975. Relationship between the level of copper in the blood plasma and liver of cattle. Journal of Animal Science 41: 911-914. https://doi.org/10.2527/jas1975.413 911x

Colakoglu EH, Yazlik OM, Kaya U, Colakoglu EC, Kurt S, Oz B, Bayramoglu R, Vural MR and Kuplulu S, 2017. MDA and GSH-Px activity in transition dairy cows under seasonal variations and their relationship with reproductive performance. Journal of Veterinary Research 61: 497-502. https://doi.org/10.1515/jvetres-2017-0067

Davis SL, Reichert LE and Niswender GD, 1971. Serum levels of prolactin in sheep as measured by radioimmunoassay. Biology of Reproduction 4: 145-153. https://doi.org/ 10.1093/biolreprod/4.2.145

Delitala G, 2009. Effect of pyridoxine on human hypophyseal trophic hormone release: a possible stimulation of hypothalamic dopaminergic pathway. Journal of Clinical Endocrinology \& Metabolism 42: 145-152. https://doi.org/ 10.1210/jcem-42-3-603

Dowelmadina IM, Elamin KM and Mousa HM, 2012. Evaluation of some serum constituents of camel during and post colostral period. International Journal of Livestock Research 2: $135-144$.

Du B, Takahashi K, Ishida GM, Nakahara K, Saito H and Kurachi $\mathrm{H}, 2006$. Usefulness of intraovarian artery pulsatility and resistance indices measurement on the day of follicle aspiration for the assessment of oocyte quality. Fertility and Sterility 85: 366-370. https://doi.org/10.1016/j.fertnstert. 2005.07.1316

Duntas LH, 2002. Thyroid disease and lipids. Thyroid 12: $287-$ 293. https://doi.org/10.1089/10507250252949405

Egbuna C and Ifemeje JC, 2017. Oxidative stress and nutrition. Tropical Journal of Applied Natural Sciences 2: 110-116. https://doi.org/10.25240/TJANS.2017.2.1.19

El-Harairy MA, Zeidan AEB, Afify AA, Amer HA and Amer AM, 2010. Ovarian activity, biochemical changes and histological status of the dromedary she-camel as affected by different seasons of the year. Nature and Sciences 8: 54-65. https://doi.org/10.7537/marsnsj080510.07

El-Zahar H, Alkablawy A, Al-Sharifi S and Swelum A, 2017. Monitoring the changes in certain hematological and biochemical parameters in camels (Camelus Dormedarius) during postpartum period. Fertility Biomarkers 1: 47-55. https://doi.org/10.14302/issn.2576-2818.jfb-17-1595

Faramarzian KH, Hajikolaei MR, Nouri ML, Mohebbi M and Shahriari A, 2016. Relationship between insulin to glucagon ratio and metabolic parameters in primiparous and multiparous dairy cows in transitional period. Iranian Journal of Ruminants Health Research 1:49-59. https://doi.org/ 10.22055/ijrhr.2016.12322

Faye B, Bengoumi M, Cleradin A, Tabarani A and Chilliard Y, 2001. Body condition score in dromedary camel, a tool for management of reproduction. Emirates Journal of Food and Agriculture 13: 1-6. https://doi.org/10.9755/ejfa.v12i1.5193

Finley PR, Williams RJ, Lichti DA and Thies AC, 1978. Evaluation of a new multichannel analyzer, "Astra-8". Clinical Chemistry 24: 2125-2131. https://doi.org/10.1093/ clinchem/24.12.2125

Firat A and Ozpmnar A, 2002. Metabolic profile of prepregnancy, pregnancy and early lactation in multiple 
lambing Saklz ewes. 1. Changes in plasma glucose, 3 hydroxybutyrate and cortisol levels. Annals of Nutrition and Metabolism 46: 57-61. https://doi.org/10.1159/000057641

Fujii J, Iuchi Y and Okada F, 2005. Fundamental roles of reactive oxygen species and protective mechanisms in the female reproductive system. Reproductive Biology and Endocrinology 3: 43. https://doi.org/10.1186/1477-7827-343

Garrel C, Fowler P and Al-Gubory K, 2010. Developmental changes in antioxidant enzymatic defences against oxidative stress in sheep placentomes. Journal of Endocrinology 205: 107-116. https://doi.org/10.1677/JOE-09-0362

Gassem M, Osman M, Rahman IA, Al-Assaf A and Alhazmy M, 2015. Chemical composition and microbial quality of Sudanese camel milk. Journal of Camel Practice and Research 21: 243-247. https://doi.org/10.5958/22778934.2014.00043.5

Gill-Sharma MK, 2009. Prolactin and male fertility: The long and short Feedback regulation, International Journal of Endocrinology pp,13. https://doi.org/10.1155/2009/687259

Harper HA, 1977. Review of Physiological Chemistry. $16^{\text {th }}$ Ed. Lange Medical Publications, California, USA. https://doi.org/10.1016/0307-4412(78)90039-0

Henry RJ, 1964. Clinical Chemistry, Principles and Technics. Harper and Row Publishers, New York, USA.

Herrera EA, Kane AD, Hansell J A, Thakor AS, Allison BJ, Niu $Y$ and Giussani DA, 2012. A role for xanthine oxidase in the control of fetal cardiovascular function in late gestation sheep. The Journal of Physiology 590: 1825-1837. http://doi.org/ 10.1113/jphysiol.2011.224576

Heydari F, Varidi MJ, Varidi M and Mohebbi M, 2015. Study on quality characteristics of camel burger and evaluating its stability during frozen storage. Food Measure 10: 148-155. https://doi.org/10.1007/s11694-015-9288-6

IBM Corp, 2013. IBM SPSS Statistics for Windows, Version 22.0. Armonk, NY: IBM Corp.

Ibrahim Maha A, Abd-El-Rahman Howid MA and Elmetwaly HA, 2017. Relationship between some biochemical parameters and hormones in milk and serum associated to reproduction in she-camel. Alexandria Journal of Veterinary Sciences 52: 190-197. https://doi.org/10.5455/ajvs.255501

Ibrahim GA and Nour IA, 2010. Physical and chemical properties of camel meat burgers. Journal of Camelid Science 3: 39-43.

Islam S, Ferdous J, Rahman MK, Akter S, Hassan MM and Islam A, 2019. Reference values for hematological and serum biochemical parameters of dromedary camel (Camelus dromedarius) in subtropical climate of Bangladesh. Advances in Animal and Veterinary Sciences 7: 232-237. https://doi.org/10.17582/journal.aavs/2019/7.4.232.237

Joshi A, Haque N, Lateef A, Patel A, Patel P and Bhalakiya N, 2017. Study on blood metabolites and leukocyte indices of kutchi camels during different stages of lactation. Journal of Animal Health and Production 5: 92-96. https://doi.org/ 10.17582/journal.jahp/2017/5.3.92.96

Kamoun M and Jemmali B, 2014. Serum progesterone level of camel (Camelus dromedarius) according to the physiological status. Journal of New Sciences 3: 125-129.

Kandiel MMM, El-Khaiat HM and Karima MM, 2016. Changes in some hematobiochemical and hormonal profile in Barki sheep with various reproductive statuses. Small Ruminant Research 136: 87-95. https://doi.org/10.1016/j.smallrumres. 2016.01.011

Kaufmann BA, 2005. Reproductive performance of camels (Camelus dromedarius) under pastoral management and its influence on herd development. Livestock Production Science 92: 17-29. https://doi.org/10.1016/j.livprodsci.2004. $\underline{06.016}$

Kessler EC, Gross JJ, Bruckmaier RM and Albrecht C, 2014. Cholesterol metabolism, transport, and hepatic regulation in dairy cows during transition and early lactation. Journal of
Dairy Science 97: 5481-5490. https://doi.org/10.3168/jds. 2014-7926

Khalifa MA, Abd El-Hamid IS and Rateb SA, 2020. Induction of synchronized multiple ovulation in dromedary camels during the early non-breeding season. Small Ruminant Research 182: 67-72. https://doi.org/10.1016/j.smallrumres.2019. $\underline{106028}$

Khalifa MA, 2012. Manipulation of postpartum fertility in onehumped she-camels during the non-breeding season under semi-arid condition. PhD Agric Sci. Thesis, Alexandria Univ, Egypt.

Khan AF, Patil SKB and Thakur AS, 2014. Lipid profile in thyroid dysfunction: A study on patients of Bastar. Annals of Clinical and Analytical Medicine 1: 12-14. https://doi.org/ 10.4328/JCAM. 1178

Konvicna J, Vargova M, Paulíkova I, Kovac G and Kostecka Z, 2015. Oxidative stress and antioxidant status in dairy cows during prepartal and postpartal periods. Acta Veterinaria 84: 133-140. https://doi.org/10.2754/avb201584020133

Koracevic D, Koracevic G, Djordjevic V, Andrejevic S and Cosic V, 2001. Method for the measurement of antioxidant activity in human fluids. Journal of Clinical Pathology 5: 356-361. http://doi.org/10.1136/jcp.54.5.356

Kurek-Gorecka A, Rzepecka-Stojko A, Gorecki M, Stojko J, Sosada M and Swierczek-Zieba G, 2014. Structure and antioxidant activity of polyphenols derived from propolis. Molecules 19: 78-101. https://doi.org/10.3390/molecules $\underline{19010078}$

LaFranchi SH, Haddow JE and Hollowell JG, 2005. Is thyroid inadequacy during gestation a risk factor for adverse pregnancy and developmental outcomes? Thyroid 15: 60-71. https://doi.org/10.1089/thy.2005.15.60

Leung AM and Farwell AP, 2010. Thyroid function testing in ambulatory practice Thyroid Function Testing 28: 155- 171. https://doi.org/10.1007/978-1-4419-1485-98

Mahran S, Elhelw R and El-Jakee J, 2020. Characterization of Staphylococcus aureus isolated from camel and human samples from Aswan governorate in Egypt. International Journal of Veterinary Science 9: 397-402.

Mohammed KME and Al-Mutairi SE, 2012. Reproductive performance of dromedary camels (Camelus dromedarius) under an intensive management system. Journal of Camel Practice and Research 19: 235-242.

Mohebbi-Fani M, Mirzaei A, Nazifi S and Tabandeh MR, 2012. Oxidative status and antioxidant enzyme activities in erythrocytes from breeding and pregnant ewes grazing natural pastures in dry season. Revue de Médecine Vétérinaire 163: 454-460.

Monaco D, Padalino B and Lacalandra GM, 2015. Distinctive features of female reproductive physiology and artificial insemination in the dromedary camel species. Emirates Journal of Food and Agriculture 27: 328-337. https://doi.org/10.9755/ejfa.v27i4.19904

Montgomery HAC and Dymock JF, 1961. The determination of nitrite in water. Analyst 86: 414-416.

Mostafa TH, Abd El-Salaam AM, Ahmadi EAA, Fadel MS, Zeidan AEB and Abdel-Khalek AE, 2018. Development of some fetal measurements and ovarian hormones during gestation period in Maghrebian she-camels under Egyptian conditions. Journal of Agriculture and Veterinary Sciences 11: 50-59. https://doi.org/10.9790/2380-1107015059

Nishikimi M, Roa NA and Yogi K, 1972. The occurrence of superoxide anion in the reaction of reduced phenazine methosulfate and molecular oxygen. Biochemical Biophysical Research Communications 46: 849-854 http://dx.doi.org/10.1016/S0006-291X(72)80218-3

Omidi A1, Fathi MH and Asiaban M, 2015. Elevated levels of blood urea nitrogen and creatinine in the last trimester of pregnancy of dromedary camels (Camelus dromedarius). Iranian Journal of Ruminants Health Research 9: 249-255. https://doi.org/10.22059/ijvm.2016.56324 
Ostrom KM, 1990. A review of the hormone prolactin during lactation. Progress in Food \& Nutrition Science 14: 1-43.

Padalino B, Rateb SA, Ibrahim NB, Monaco D, Lacalandra GM and El-Bahrawy KA, 2016. Behavioral indicators to detect ovarian phase in the dromedary she-camel. Theriogenology 85: 1644-1651. https://doi.org/10.1016/j.theriogenology. 2016.01 .027

Perez RL, Machiavelli GA, Romano MI and Burdman JA, 1986. Prolactin release, oestrogens and proliferation of prolactinsecreting cells in the anterior pituitary gland of adult male rats. Journal of Endocrinology 108: 399-403. https://doi.org/ $\underline{10.1677 / \text { joe. } 0.1080399}$

Pratap NB, Manjunatha M and Al-Bulushi S, 2012. Incidence of early pregnancy loss in dromedary camels (Camelus dromedarius). $3^{\text {rd }}$ ISOCARD Int Conf Sultanat of Oman 38: 108.

Quzy I, Anwar S and Purohit GN, 2013. Hormonal management of ovarian activity in breeding camels two months ahead of the natural breeding season. Camel: International Journal of Veterinary Science 1: 37-49.

Rabiee AR and Lean IJ, 2000. Uptake of glucose and cholesterol by the ovary of sheep and cattle and the influence of arterial LH concentrations. Animal Reproduction Science 64: 199209. https://doi.org/10.1016/s0378-4320(00)00208-6

Rateb SA, Abd El-Hamid IS, Khalifa MA, Ibrahim NH, Younis F and El-Rayesa M, 2019. Influence of clomiphene citrate on induced ovarian hyperstimulation and subsequent fertility in Damascus goats. Small Ruminant Research 175: 37-45. https://doi.org/10.1016/j.smallrumres.2019.04.005

Rawy MS, Derar RI, El-Sherry TM and Megahed GA, 2014. Plasma steroid hormone concentrations and blood flow of the ovarian structures of the female dromedary (Camelus dromedarius) during growth, dominance, spontaneous ovulation, luteinization and regression of the follicular wave. Animal Reproduction Science 148: 137-144. https://doi.org/ 10.1016/j.anireprosci.2014.05.004

Rhind SM, Robinson JJ, Chesworth JM and Crofts RMJ, 1980. Effects of season, lactation and plane of nutrition on prolactin concentrations in ovine plasma and the role of prolactin in the control of ewe fertility. Journal of Reproduction and Fertility 85: 145-152. https://doi.org/ 10.1530/jirf.0.0580145

Saeed A, Khan A and Hussein MM, 2009. Change in biochemical profile of pregnant camels (Camelus dromedarius) at term. Comparative Clinical Pathology 18: 139-143. https://doi.org/10.1007/s00580-008-0763-x

Salman $M$ and Afzel M, 2004. Seasonal variations in hematological and serum biochemical parameters in racing camels. Journal of Camelid Science 1: 63-65. http://doi.org/10.1.1.137.2350

Satoh K, 1978. Serum lipid peroxide in cerebrovascular disorders determined by a new colorimetric method. Clinica Chimica Acta 90: 37-43. http://doi.org/10.1016/0009-8981(78) 90081-5

Scheletter G and Nussel E, 1975. Quantitative enzymatic colorimetric determination of triglycerides in serum or plasma. Arbeitsmed Sozialmed Pracentimed 10: 25.

Serur BH, El-Kon II and Heleil BA, 2006. Ovarian activity and hormonal profile in she-camel. International Science Conference, Kingdom of Saudi Arabia 3: 1142-1155.

Sharma N, Singh NK, Singh OP, Pandey V and Verma PK, 2011. Oxidative stress and antioxidant status during transition period in dairy cows. Asian-australas Journal of Animal Science 24: 479-484. http://doi.org/10.5713/ajas.2011. $\underline{10220}$

Shedeed HA, Farrag B, Elwakeel Eman A, Abd El-Hamid IS and El-Rayes MA-H, 2019. Propolis supplementation improved productivity, oxidative status, and immune response of Barki ewes and lambs. Veterinary World 12: 834-843. http://doi.org/10.14202/vetworld.2019.834-843
Shkolnik K, Tadmor A, Ben-Dor S, Nevo N, Galiani D and Dekel $\mathrm{N}$, 2011. Reactive oxygen species are indispensable in ovulation. Proceedings of the National Academy of Sciences 108: 1462-1467. http://doi.org/10.1073/pnas.1017213108

Skidmore JA, 2005. Reproduction in dromedary camels: An update. Animal Reproduction 2: 161-171.

Sordillo LM, Boyle ON, Gandy JC, Corl CM and Hamilton E, 2007. Shifts in thioredoxin reductase activity and oxidant status in mononuclear cells obtained from transition dairy cattle. Journal of Dairy Science 90: 1186-1192. https://doi.org/10.3168/jds.S0022-0302(07)71605-3

Sordillo LM and Aitken SL, 2009. Impact of oxidative stress on the health and immune function of dairy cattle. Veterinary Immunology and Immunopathology 128: 104-109. http://doi.org/10.1016/j.vetimm.2008.10.305

Swelum AA and Alowaimer AN, 2015. The efficacy of CIDR in synchronizing the follicular wave in dromedary camels (Camelus dromedarius) during the breeding season. Theriogenology 84: 1542-1549. https://doi.org/10.1016/ j.theriogenology.2015.08.003

Symonds ME, Stephenson T, Gardner DS and Budge H, 2007. Long-term effects of nutritional programming of the embryo and fetus: mechanisms and critical windows. Reproduction, Fertility and Development 19: 53-63. https://doi.org/ $\underline{10.1071 / \mathrm{rd} 06130}$

Tharwat M, Oikawa S and Buczinski S, 2012. Ultrasonographic prediction of hepatic fat content in dairy cows during the transition period. Journal of Veterinary Science and Technology 3: 149-161. https://doi.org/10.4172/2157 $\underline{7579.1000111}$

Tharwat M, Ali A, Al-Sobayil F, Selim L and Abbas H, 2015. Hematobiochemical profile in female camels (camelus dromedarius) during the periparturient period. Journal of Camel Practice and Research 22: 101-106. https://doi.org/10.5958/2277-8934.2015.00016.8

Tietz NW, 1976. Fundamentals of Clinical Chemistry. W.B. Saunders Co., Philadelphia.

Tinson AH, Kuhad KS, Singh K, Sambyal R, Mugheiry A, Rahman A and Al Masri J, 2001. Twinning in camels. Emirates Journal of Food and Agriculture 13: 71-73. https://doi.org/10.9755/ejfa.v13i1.5234

Trinder P, 1969. Determination of glucose in blood using glucose oxidase with an alternative oxygen acceptor. Annals of Clinical Biochemistry 6: 24-27.

Turk R, Podpecan O, Mrkun J, Flegar-Mestric Z, Perkov S and Zrimsek P, 2015. The effect of seasonal thermal stress on lipid mobilisation, antioxidant status and reproductive performance in dairy cows. Reproduction in Domestic Animals 50: 595-603. https://doi.org/10.1111/rda.12534

Wang S, He G, Chen M, Zuo T, Xu W and Liu X, 2017. The role of antioxidant enzymes in the ovaries. Oxidative Medicine and Cellular Longevity 7: 2-14. https://doi.org/10.1155/ 2017/4371714

Weichslbaum TE, 1964. An accurate and rapid method for the determination of proteins in small amount of blood serum and plasma. American Journal of Clinical Pathology 16: pp 40.

Wooding FBP, Ozturk M, Skidmore JA and Allen WR, 2003. Developmental changes in localization of steroid synthesis enzymes in camelid placenta. Reproduction 126: 239-247. https://doi.org/10.1530

Young DS, Thomas DW, Friedman RB and Pestaner LC, 1972. Effects of drugs on clinical laboratory tests. Clinical Chemistry 18: 1041-1303. https://doi.org/10.1093/clinchem/ $\underline{18.10 .1041}$

Zeidan AEB, Abd El-Salaam AM, El-Malky, OM, Ahamdi EAA, Sarhan DMA and Daader AH, 2008. Biochemical and histological changes in the ovary of the dromedary camel during breeding and non-breeding seasons. Egyptian Journal of Basic and Applied Physiology 7: 287-308. 